\title{
Purification and Characterization of Two Antimicrobial Peptides from Bacterial-challenged Haemolymph of Bombyx mori Larva.
}

\author{
AlaaEddeen M. Seufi ${ }^{1}$, Ghada M. EI Bassiony ${ }^{1}$ and Safinz S. Ibrahim ${ }^{2}$ \\ 1- Entomology Department, Faculty of Science, Cairo University, Giza, Egypt. \\ 2- Biochemistry Department, Faculty of Pharmacy, Cairo University, Cairo, Egypt.
}

\section{ABSTRACT}

Defense peptides and proteins constitute key factors in insect humoral immune response against invading microorganisms. In this study, biochemical approach was designed to purify and characterize two peptides which appeared in larval haemolymph of $B$. mori after bacterial challenge. The results showed a significant increase of total protein of the bacterial-challenged haemolymph and then declined over time. This suggested that the AMPs are upregulated and released in haemolymph as "acute phase response" of the insect. Full antimicrobial activity was observed for the immune haemolymph at $24 \mathrm{~h}$ p.i. Fractionation of the immune haemolymph extract on a reversed phase $\mathrm{C}-18$ column allowed effective separation of 5 fractions containing mainly proteins and peptides of molecular masses below $20 \mathrm{kDa}$. After fractionation, one out of three fractions (fraction\# 5) exhibited the strongest antimicrobial activity. Finally, two peptides $(5.8$ and $4.3 \mathrm{KDa})$ were purified and one of them $(4.3 \mathrm{KDa})$ showed full antimicrobial activity and very weak hemolytic activity up to concentration of $100 \mu \mathrm{g} / \mathrm{ml}$. These results were consistent to the results of quantitative protein analysis. Conclusively, this study demonstrated that the antimicrobial activity of the immune haemplymph is related to the presence of two antimicrobial peptides.

Keywords: Bombyx mori, antimicrobial peptides, HPLC, hemolytic activity.

\section{INTRODUCTION}

The high rate of emerging multiresistant bacterial and viral strains resulted in increased demands for new effective antibiotics. In such cases, insufficient antibiotic research and use of less effective antibiotics could have bad impacts on human and/ or animal health and productivity. The first case of bacterial resistance to several classes of antibiotics was documented in 1977 (Jacobs et al., 1978) and it can resist a whole host of drugs, 26 years later (Reinert et al., 2005). In addition, several new bacterial diseases have been discovered in the past decades. In this context, there is an urgent need for a new generation of antibiotics to complement the panel of drugs that are available to the clinicians and to provide new tools for multitherapy treatment (Bulet and Stöcklin, 2005). For decades, one major area of interest for the discovery and study of new antibiotics was the investigation of antimicrobial peptides (AMPs) derived from insect immune defense reactions. Defense peptides are key factors in innate immunity against bacteria and fungi in vertebrates as well as invertebrates. Particularly, in insects which lack an adaptive immune system, antimicrobial peptides play a crucial role in fighting against invading pathogens (Hertu et al., 1998, Irving et al., 2004, Tzou et al., 2004). This issue has demonstrated alternative antimicrobial strategies, due to insect immune defense relies solely on innate immunity (Hoffman et al., 1998). One component of the defense weapons developed by insects to rapidly 
eliminate invading pathogens is the fast and massive production of potent AMPs (Hertu et al., 1998, Bulet et al., 2003). AMPs are rapidly and transiently synthesized mainly in insect fat body (functional equivalent of mammalian liver) and in certain blood cells, and then rapidly released into haemolymph, where they act synergistically against microorganisms. They are synthesized in response to microbial infection or septic body injury (Bulet et al., 2003). From a large number of about 890 AMPs of eukaryotic origin identified to date, more than 180 were described in insects. Peptides exhibiting antimicrobial activity are mainly small $(\approx 5 \mathrm{kDa})$, amphipathic, cationic molecules. On the basis of amino acid sequence and structural characteristics they are divided into three broad classes: (i) linear a-helical peptides without cysteine residues, e.g. cecropins; (ii) peptides whose structure is stabilized by disulfide bridges (cysteine-stabilized peptides), e.g. defensins; (iii) peptides with an overrepresentation of proline and/or glycine residues (Bulet et al., 1999). Generally, AMPs are assumed in the near future as an alternative for the nowadays classical antibiotics. The advantages of AMPs are: selectivity, fast killing, broad antimicrobial spectra and no resistance development (Boman, 2003, Matsuzaki, 1999).

In this paper, we report on purification, partial characterization, antimicrobial and hemolytic activity spectra of two peptides present simultaneously in the immune haemolymph of B. mori larvae. Such peptides could be useful in the control of plant, human and veterinary microbial infection.

\section{MATERIALS AND METHODS}

\section{Insects and bacterial strains}

Disease free laying (DFL) of a silkworm breed was brushed and reared separately as per the standard rearing techniques described by Dandin et al. (2003) on fresh leaves of mulberry. The $3^{\text {rd }}$ to $5^{\text {th }}$ instar larvae were kept under controlled conditions $\left(25{ }^{\circ} \mathrm{C}, 65-70 \% \mathrm{RH}\right.$ and $14 \mathrm{~L}$ : $10 \mathrm{D}$ photoperiod cycle) at the insectary of the Department of Entomology, Faculty of Science, Cairo University, Giza, Egypt.

The experiments were conducted on the $5^{\text {th }}$ instar larvae and repeated thrice at three different times.

Three gram $(+)$ bacteria, Staphylococcus aureus, Bacillus subtilis and Streptococcus sanguinis and four gram (-) bacteria, Escherichia coli $\left(\mathrm{D}_{31}\right)$, Psuedomonas aeruginosa, Proteus mirabilis and Klebsiella pneumoniae were obtained from the Unit for Genetic Engineering and Agricultural Biotechnology, Faculty of Agriculture, Ain Shams University and used for insect immunization and antibacterial activity assay. Bacteria were grown in a peptone medium (1\%), supplemented with $1 \%$ meat extract and $0.5 \% \mathrm{NaCl}$, at $37^{\circ} \mathrm{C}$ in a rotary shaker.

\section{Insect immunization and haemolymph collection}

Insect immunization was performed by injecting 20 newly moulted $5^{\text {th }}$ instar larvae with $10 \mu \mathrm{l}$ of approximately $1 \times 10^{6}$ (cells/ ml) viable, log phase bacteria dissolved in membrane-filtered saline using a thin-needled microsyringe. Bacterial strains were used for immunization separately or in combinations (Table 1). Haemolymph was sampled at 24,48 and $72 \mathrm{~h}$ p.i. at $4{ }^{\circ} \mathrm{C}(500 \mu \mathrm{l} / \mathrm{each})$, containing few crystals of phenylthiourea to prevent melanization. Usually, $10 \mathrm{ml}$ of haemolymph was collected, from about 15 to 20 larvae (irrespective of sex), by piercing a proleg with a fine, sterile needle. Haemolymph was centrifuged for $15 \mathrm{~min}$ at $1,800 \mathrm{rpm}$, then the cell-free haemolymph was aliquoted ( $100 \mu \mathrm{l}$ to $1 \mathrm{ml}$ each), and stored at $-80{ }^{\circ} \mathrm{C}$ for a weak until investigated. The same procedures were applied to the control group except it was injected with saline without bacteria. 


\section{Quantitative protein analysis}

Total protein concentration was quantified spectrophotometrically in both the control and the bacterial-challenged samples using Bio-Rad protein assay kit (BioRad, USA) following the manufacturer's protocol. The difference between the control and the treated samples was considered accumulated AMP in the haemolymph (subtraction method). Standard curve was constructed by using Bovine Gamma Globulin (BGG). Haemolymph volumes were corrected for total protein concentration all over the antibacterial experiments.

\section{Preparation of haemolymph extracts}

The cell-free haemolymph was used for extraction of peptides. Acidic/ methanolic extracts of cell-free haemolymph were obtained by the method adapted from Schoofs et al. (1990). The haemolymph was diluted 10 times with the extraction solution consisting of methanol: glacial acetic acid: water (90: 1: 9, v/ v/ v) and mixed thoroughly. Precipitated proteins were pelleted by cooling centrifugation at 14000 rpm for $30 \mathrm{~min}$. The obtained supernatant was collected, freeze-dried and the pellet was dissolved in $0.1 \%$ trifluoroacetic acid (TFA). For lipid removal from the extract, the same volume of $n$-hexane was added, the sample was vortexed and centrifuged at $14000 \mathrm{rpm}$ for $10 \mathrm{~min}$ at $4{ }^{\circ} \mathrm{C}$. The upper fraction containing lipids was removed and an equal volume of ethyl acetate was added to the water-soluble fraction (containing peptides). After vortexing and centrifugation the water-soluble fraction was freezedried and stored at $-80^{\circ} \mathrm{C}$ until needed.

\section{Purification of immune haemolymph peptides}

The freeze-dried immune haemolymph, deprived of lipids, was dissolved in $0.1 \%$ TFA and subjected to the first step of purification using a Supelcosil LC-18-DB $4.6 \mathrm{~mm} \times 250 \mathrm{~mm}$ column, two buffer sets (A: 0.1\% TFA (v/v), B: $0.07 \%$ TFA, $80 \%$ acetonitrile $(\mathrm{v} / \mathrm{v}))$, and a linear gradient from 20 to $70 \%$ of buffer B over $30 \mathrm{~min}$ and 1 $\mathrm{ml} / \mathrm{min}$ flow rate. This step and all next chromatographic steps were performed on a Dionex P680 HPLC system (Dionex, Sunnyvale, CA, USA). The resulting fractions were subjected to freeze-drying, redissolved in water and visualized by staining with Coomassie Brilliant Blue after gel electrophoresis. Antimicrobial activity of the obtained fractions was determined as described below. Identified peptide-containing fractions exhibiting antibacterial activity were then subjected to the second step of purification using gel filtration chromatography on a Superose 12 HR 10/ 30 column (Pharmacia Biotech, Uppsala, Sweden), $50 \mathrm{mM}$ ammonium acetate buffer $\mathrm{pH} 7.5$ supplemented with $30 \%(\mathrm{v} / \mathrm{v})$ acetonitrile and $0.4 \mathrm{ml} / \mathrm{min}$ flow rate. The collected peptide-containing fractions were finally purified to homogeneity using the previously described Supelcosil LC-18-DB column and a TFA/ water/ acetonitrile buffer set as experienced (many gradients were tried). The purified peptides were freeze-dried and stored at $-80{ }^{\circ} \mathrm{C}$ until needed. Before use for antimicrobial activity tests, they were dissolved in apyrogenic water.

\section{Polyacrylamide gel electrophoresis (PAGE) and localization of antibacterial activity}

Native-PAGE of the collected samples of haemolymph at 24, 48 and $72 \mathrm{~h}$ p.i. was carried out to assess the induction of antibacterial peptides in the different haemolymph samples. It was carried out in $15 \%$ polyacrylamide gels $\mathrm{pH} 4$, using a discontinous buffer system (Gabriel, 1971), but omitting the stacking gel. The acrylamide/ bisacrylamide ratio was 60: 0.8 . The gels were run at $200 \mathrm{~V}$ until the tracker dye (methyl green) was running off the gel (approximately $2.5 \mathrm{~h}$ ).

To localize bands with antibacterial activity the gels were incubated for one hour in a rich bacterial medium which contained $0.2 \mathrm{M}$ sodium phosphate $\mathrm{pH} 7.4$, and 
streptomycin, $100 \mu \mathrm{g} / \mathrm{ml}$. The gel was then overlaid with $5 \mathrm{ml}$ of melted agar, $0.6 \%$ in the same medium, containing about $2 \times 10^{5}$ viable $E$. coli $\mathrm{D}_{31}$ cells. On top of this was poured another layer of agar without bacteria, and the gel was incubated at $37^{\circ} \mathrm{C}$ overnight. After incubation overnight at $37^{\circ} \mathrm{C}$, antibacterial activity in the bands was visualized as areas without bacterial growth.

Sodium dodecylsulfate (SDS)-PAGE of denatured proteins was carried out in $20 \%$ polyacrylamide gels $\mathrm{pH} 8.8$, in a discontinous buffer (Maizel, 1971), but omitting the stacking gel. The acrylamide/ bisacrylamide ratio was 50: 1. The gels contained no SDS before electrophoresis. The protein samples were pretreated with $1 \%$ SDS and $1 \% \beta$-mercaptoethanol for 5-10 minutes at $100{ }^{\circ} \mathrm{C}$. The gels were run at $100 \mathrm{~V}$ until the tracker dye (bromphenol blue) was leaving the gel (approximately 6 h). All gels were fixed in 20\% 5-sulfosalicylic acid, stained with Coomassie Brilliant Blue $\mathrm{R}_{250}$ in $7 \%$, acetic acid, and destained in $7 \%$ acetic acid.

\section{Antimicrobial assay}

In vitro antimicrobial studies were carried out on the crude immunized haemolymph, the fractions containing peptides of low molecular weight and the purified peptides, from the HPLC experiment. Antimicrobial activity was estimated by the agar disk diffusion method with minor modifications (Favel et al., 1994, NCCLS, 1997). Five milliliters of $0.6 \%$ melted LB agar $\left(52{ }^{\circ} \mathrm{C}\right)$ were mixed with 100 $\mu \mathrm{l}$ of viable bacterial suspension $\left(1.6 \times 10^{9} \mathrm{cells} / \mathrm{ml}\right)$, and poured into a $15 \mathrm{~cm}$ plastic dish. Five microliters of each haemolymph and protein samples were applied to a 6 $\mathrm{mm}$ diameter paper disk and incubated at $37{ }^{\circ} \mathrm{C}$. Haemolymph volumes were corrected for total protein concentration all over the experiment. Penicillin (10 $\mathrm{mg}$ /disc; obtained from Sigma) and normal saline solution were used as positive and negative controls, respectively. S. aureus, B. subtilis, S. sanguinis, E. coli $\left(\mathrm{D}_{31}\right), P$. aeruginosa, $P$. mirabilis, and $K$. pneumoniae bacteria were used for testing the antimicrobial activity. Inhibition zone diameters of five replicates were measured after 24-48 $\mathrm{h}$. The degree of growth inhibition was quantitatively evaluated after $16 \mathrm{~h}$ by comparison with the growth inhibition resulting from the positive control.

\section{Hemolytic assay}

Hemolytic assay was performed using human, cow and rabbit erythrocytes as previously described with slight modification (Ryge and Hansen, 2005). Briefly, the erythrocytes were washed three times $(3000 \mathrm{rpm})$ with phosphate buffered saline $(0.15 \mathrm{M}, \mathrm{pH} 7.2)$ and diluted to a final concentration of $0.5 \%$ in the same buffer (PBS). To each well of a polypropylene microtiter plate $75 \mu \mathrm{l}$ of the diluted erythrocytes and $75 \mu 1$ of peptide solution at 100, 75, 50, 25 and $12.5 \mu \mathrm{g} / \mathrm{ml}$ were added. After incubated for $1 \mathrm{~h}$ at $37^{\circ} \mathrm{C}$, samples were centrifuged at $4000 \mathrm{rpm}$ for 10 min and $100 \mu$ of the supernatants were transferred to a new 96-well microtiter plates. The optical density of supernatant was determined at $405 \mathrm{~nm}$ with an ELISA plate reader. Negative control (zero hemolysis) and positive control (100\% hemolysis) were achieved by suspending the erythrocytes in $10 \mathrm{mM}$ PBS and Triton X-100, respectively. The hemolysis percentage was calculated as follows: [( $\left.\mathrm{A}_{\text {peptide }}-\mathrm{A}_{\mathrm{PBS}}\right) /$ $\left.\left(\mathrm{A}_{\text {Triton }}-\mathrm{A}_{\mathrm{PBS}}\right)\right] \mathrm{X}$ 100. All hemolysis determinations were performed in triplicate and are the average of three independent determinations using the same stock solution.

\section{RESULTS}

\section{Quantitative protein analysis}

Quantitative protein analysis of the crude haemolymph of control and bacterialchallenged B. mori was determined at 24, 48 and $72 \mathrm{~h}$ p.i. (Table 1). Statistical 
analysis of the data revealed that the increase of total protein concentration in all cases of bacterial-challenged insects were significant, when compared to control, at 24 and 48 h p.i. $D f, F$ and $P$ values were illustrated in Table (1). Meanwhile, no significant difference was observed between control and bacterial-challenged insects, at $72 \mathrm{~h}$ p.i. $(d f=9, F=0.4$ and $P=0.9$ ). At $24 \mathrm{~h} \mathrm{p.i,} \mathrm{the} \mathrm{total} \mathrm{protein} \mathrm{concentration} \mathrm{of} \mathrm{the}$ haemolymph immunized with a gram (-) bacterium was significantly higher $(P<0.01)$ than that immunized with a gram $(+)$ bacterium or with a combination of both, as well (Table 1). It was observed that the increase in total protein concentration of bacterialchallenged insects was significantly higher $(P<0.001)$ than control at $48 \mathrm{~h} \mathrm{p}$.i. However, no significant difference $(P>0.05)$ was observed between gram $(-)$ and gram $(+)$ bacterial challenge at $48 \mathrm{~h}$ p.i. (Table 1). In addition, no significant difference $(P>0.05)$ was observed between control and bacterial-challenged insects at 72 h p.i. (Table 1).

Generally, the total protein concentration decreases over time from 24 to $72 \mathrm{~h}$ p.i. within the same treatment. This decrease was statistically significant $(P<0.05)$ in all cases except the decrease between 24 and $48 \mathrm{~h}$ p.i. in the case of combination, combination $_{3}$, and $S$. sanguinis bacteria $(P>0.05)$. No significant difference $(P>$ 0.05 ) was observed in the case of control (Table 1).

Table 1: Quantitative protein analysis of the control and the immune haemolymph of $S$. littoralis at different times post-immunization by different bacterial srains.

\begin{tabular}{|c|c|c|c|}
\hline \multirow[t]{2}{*}{ Immunization by } & \multicolumn{3}{|c|}{$\begin{array}{l}\text { Protein concentration at different hours post-infection }(\mu \mathrm{g} / \mathrm{ml}) \\
\qquad \text { Mean } \pm \text { S.E. }\end{array}$} \\
\hline & 24 h p.i. & 48 h p.i. & 72 h p.i. \\
\hline Cont-H* & $672.0 \pm 7.9^{\mathrm{a}^{* *}}$ & $649.4 \pm 6.9^{\mathrm{a}}$ & $676.4 \pm 6.2^{\mathrm{a}}$ \\
\hline E. coli (-ve) & $2008.8 \pm 11.2^{\mathrm{b}}$ & $974.8 \pm 3.3^{b}$ & $712.4 \pm 2.0^{\mathrm{a}}$ \\
\hline S. aureus (+ve) & $1106.8 \pm 41.7^{\mathrm{bc}}$ & $859.6 \pm 29.9^{\mathrm{ab}}$ & $708.6 \pm 9.7^{\mathrm{a}}$ \\
\hline Combination & $1097.6 \pm 46.5^{\mathrm{bc}}$ & $920.2 \pm 24.7^{b}$ & $716.4 \pm 9.9^{\mathrm{a}}$ \\
\hline P. vulgaris (-ve) & $2087.4 \pm 49.8^{b}$ & $960.8 \pm 28.7^{b}$ & $702.6 \pm 14.4^{\mathrm{a}}$ \\
\hline B. subtilis (+ve) & $1186.6 \pm 47.2^{\mathrm{bc}}$ & $933.8 \pm 49.9^{b}$ & $709.2 \pm 9.5^{\mathrm{a}}$ \\
\hline Combination & $1074.8 \pm 52.2^{\mathrm{bc}}$ & $932.2 \pm 21.2^{b}$ & $696.4 \pm 48.5^{\mathrm{a}}$ \\
\hline K. pneumoniae (-ve) & $2097.4 \pm 38.0^{b}$ & $977.0 \pm 46.5^{b}$ & $722.6 \pm 28.0^{\mathrm{a}}$ \\
\hline S. sanguinis (+ve) & $1140.0 \pm 60.9^{\mathrm{bc}}$ & $982.4 \pm 78.2^{b}$ & $719.4 \pm 13.1^{\mathrm{a}}$ \\
\hline Combination & $1012.8 \pm 15.6^{\mathrm{bc}}$ & $953.8 \pm 20.1^{b}$ & $731.2 \pm 42.6^{\mathrm{a}}$ \\
\hline$D f, F, P$ & $9,156.4,0.0$ & $9,7.1,0.0$ & $9,0.4,0.9$ \\
\hline
\end{tabular}

* Cont-H: Untreated crude haemolymph.

**Means with different letters are significant at 95\% confidence limits.

\section{Purification of the immune haemolymph peptides}

The fractionation of the immune haemolymph extract on a reversed phase C-18 column allowed effective separation of 5 fractions containing mainly proteins and peptides of molecular masses below $20 \mathrm{kDa}$ (Fig. 1E). The obtained fractions were tested for antimicrobial activity and relative high level of antibacterial activity against gram (+) and gram (-) was detected in fractions\# 2, 3 and 5, containing the most abundant low-molecular weight peptides (Table 3). For further purification, the fractions\# 2, 3 and 5, containing the most abundant low-molecular weight peptides (below $7 \mathrm{kDa}$ ) and exhibiting high antibacterial activity, were chosen. The second step embraced gel filtration chromatography and allowed isolation of single peptide 
components from the chosen fractions (Fig. 1E). Although each fraction resolved during gel filtration into two separate peaks (Fig. 1C and D), only two low-molecular weight peptides were chosen to be tested for antimicrobial activity (peptide\# A and $\mathrm{B})$. These peptides were then desalted and purified to homogeneity by a reversed phase chromatography step on a $\mathrm{C}-18$ column. The final peptide preparation gave single bands on SDS-PAGE gels and single peaks on a C-18 column.

\section{Antimicrobial assay}

Tables (2-4) show a summary of the antimicrobial screening of the crude immunized haemolymph, three active fractions and two purified peptides, based on microbial growth inhibition zone (in $\mathrm{mm}$ ). Based on the quantitative protein analysis, antimicrobial activity of the crude Klebsiella-immunized haemolymph (the highest protein concentration) was investigated at 24,48 and $72 \mathrm{~h}$ p.i. (Table 2). Significant increase in antimicrobial activity of the immunized haemolymph (inhibition zone more than positive control) was found against gram (-) and gram (+) bacteria at $24 \mathrm{~h}$ p.i.

Table 2: Antimicrobial activity of the immunized haemolymph (K. pneumoniae) collected at different times post-immunization, against gram $(-)$ and gram $(+)$ bacteria.

\begin{tabular}{|l|c|c|c|c|c|c|}
\hline \multirow{2}{*}{$\begin{array}{c}\text { Microorganism } \\
\text { (gram stain) }\end{array}$} & \multicolumn{4}{|c|}{ Antimicrobial activity of the immunized haemolymph collected at } \\
\cline { 2 - 7 } & \multicolumn{2}{|c|}{$24 \mathrm{~h} \mathrm{p.i.*}$} & \multicolumn{2}{c|}{$48 \mathrm{~h} \mathrm{p.i.}$} & \multicolumn{3}{c|}{$72 \mathrm{~h} \mathrm{p.i.}$} \\
\cline { 2 - 7 } & $24 \mathrm{~h} * *$ & $48 \mathrm{~h}$ & $24 \mathrm{~h}$ & $48 \mathrm{~h}$ & $24 \mathrm{~h}$ & $48 \mathrm{~h}$ \\
\hline E. coli (-ve) & ++ & +++ & ++ & ++ & $(+)$ & + \\
\hline K. pneumoniae (-ve) & +++ & +++ & ++ & ++ & $(+)$ & + \\
\hline P. vulgaris (-ve) & ++ & +++ & ++ & ++ & $(+)$ & + \\
\hline B. subtilis (+ve) & +++ & +++ & ++ & +++ & + & + \\
\hline S. aureus (+ve) & ++ & +++ & + & ++ & $(+)$ & + \\
\hline S. sanguinis (+ve) & +++ & +++ & ++ & +++ & + & + \\
\hline
\end{tabular}

*: Time of sampling post-immunization.

**: Time of taking reading.

$(+)$ : Inhibition zone less than $1 \mathrm{~mm}$ surrounding the $6 \mathrm{~mm}$ paper disk

+ : Inhibition less than positive control.

++ : Inhibition comparable to positive control.

+++ : Inhibition more than $10 \mathrm{mg}$ penicillin; inhibition zones of references $=13 \pm 1 \mathrm{~mm}$ diam.

Table (3): Antimicrobial activity of the fractions containing low molecular weight peptides, against gram (-) and gram (+) bacteria.

\begin{tabular}{|l|c|c|c|c|c|c|}
\hline \multirow{2}{*}{$\begin{array}{c}\text { Microorganism } \\
\text { (gram stain) }\end{array}$} & \multicolumn{3}{|c|}{ Antimicrobial activity of the immune haemolymph collected at } \\
\cline { 2 - 7 } & \multicolumn{2}{|c|}{ Fraction\# 2} & Fraction\# 3 & \multicolumn{2}{c|}{ Fraction\# 5 } \\
\cline { 2 - 7 } & $24 \mathrm{~h}^{*}$ & $48 \mathrm{~h} *$ & $24 \mathrm{~h}$ & $48 \mathrm{~h}$ & $24 \mathrm{~h}$ & $48 \mathrm{~h}$ \\
\hline E. coli (-ve) & + & ++ & ++ & +++ & +++ & +++ \\
\hline K. pneumoniae (-ve) & $(+)$ & + & + & ++ & +++ & +++ \\
\hline P. vulgaris (-ve) & + & ++ & ++ & +++ & +++ & +++ \\
\hline B. subtilis (+ve) & ++ & +++ & +++ & +++ & ++ & +++ \\
\hline S. aureus (+ve) & ++ & ++ & +++ & +++ & +++ & +++ \\
\hline S. sanguinis (+ve) & + & ++ & ++ & +++ & +++ & +++ \\
\hline
\end{tabular}

*: Reading taken after this time.

$(+)$ : Inhibition zone less than $1 \mathrm{~mm}$ surrounding the $6 \mathrm{~mm}$ paper disk

+ : Inhibition less than positive control.

++ : Inhibition comparable to positive control.

+++ : Inhibition more than $10 \mathrm{mg}$ penicillin; inhibition zones of references $=13 \pm 1 \mathrm{~mm}$ diam. 
Table 4: Antimicrobial activity of the purified antimicrobial peptides on gram (-) and gram (+) bacteria.

\begin{tabular}{|c|c|c|c|c|}
\hline \multirow{3}{*}{$\begin{array}{c}\text { Microorganism } \\
\text { (gram stain) }\end{array}$} & \multicolumn{4}{|c|}{ Antimicrobial activity of the immunized haemolymph collected at } \\
\hline & \multicolumn{2}{|c|}{ Peptide\# A } & \multicolumn{2}{|c|}{ Peptide\# B } \\
\hline & $24 \mathrm{~h} *$ & $48 \mathrm{~h} *$ & $24 \mathrm{~h}$ & $48 \mathrm{~h}$ \\
\hline E. coli (-ve) & ++ & +++ & +++ & +++ \\
\hline K. pneumoniae (-ve) & ++ & ++ & +++ & +++ \\
\hline P. vulgaris (-ve) & + & ++ & ++ & +++ \\
\hline B. subtilis (+ve) & +++ & +++ & +++ & +++ \\
\hline S. aureus (+ve) & ++ & ++ & ++ & +++ \\
\hline S. sanguinis (+ve) & +++ & +++ & +++ & +++ \\
\hline
\end{tabular}

*: Reading taken after this time.

$(+)$ : Inhibition zone less than $1 \mathrm{~mm}$ surrounding the $6 \mathrm{~mm}$ paper disk

+ : Inhibition less than positive control.

++ : Inhibition comparable to positive control.

+++ : Inhibition more than $10 \mathrm{mg}$ penicillin; inhibition zones of references $=13 \pm 1 \mathrm{~mm}$ diam.

However, it was comparable to or more than the positive control at $48 \mathrm{~h}$ p.i. The least activity of the immunized haemolymph was observed at $72 \mathrm{~h}$ p.i. Generally, antimicrobial activity was comparable to or less than the positive control in the case of E. coli, P. vulgaris and S. aureus bacteria (Table 1).

The crude Klebsiella-immunized haemolymph was subjected the first step of purification and five fractions were obtained from this step of purification. These fractions were analyzed by SDS-PAGE (Fig. 1E), and three of them were found to contain abundant low-molecular weight peptides (fractions\# 2, 3 and 5). The antimicrobial activity of these three fractions was investigated (Table 3). Notably, fraction\# 5 exhibited the strongest antimicrobial activity (more than the positive control) among the three tested fractions. The activity was comparable to or more than the positive control in the case of fraction\# 3. However, the least activity was observed in the case of fraction\# 2. K. pneumoniae showed more resistance to fractions\# 2 and 3, followed by E. coli, P. vulgaris and S. sanguinis. It is worthy mentioned that the fraction\# 5 displayed its full antimicrobial activity against all tested bacteria at $48 \mathrm{~h}$ post-treatment (Table 3 ).

The three fractions were subjected to the second step of purification and two promising antimicrobial peptides (peptide\# A and B) were selected to be tested for antimicrobial activity (Table 4 and Fig. 1E). The full antimicrobial activity of the peptide\# B (more than the positive control) was observed at $48 \mathrm{~h}$ post-treatment. However, the antimicrobial activity of the peptide\# A was comparable to or more than the positive control, except in the case of P. vulgaris (Table 4). Generally, the purified peptides exhibited a broad antimicrobial activity against all tested gram $(+)$, gram $(-)$ bacteria but notably was relatively less active against $S$. aureus and $P$. vulgaris at $24 \mathrm{~h}$ post-treatment (Table 4).

\section{Hemolytic activity analysis}

The purified peptides (A and B) evidenced no or very weak hemolytic activity against human, cow and rabbit red blood cells, even up to $50 \mu \mathrm{g} / \mathrm{ml}$ concentration (Table 5). Peptide\# B exhibited weaker hemolytic activity than peptide\# A. Acceptable percentages of hemolysis $(2.8-5 \%)$ were observed at higher concentrations (75 and $100 \mu \mathrm{g})$. Hemolytic activity of the peptide\# A toward human RBCs did not exceed a maximum point of $4.4 \%$ at $100 \mu \mathrm{g}$ concentration. However, the slight increase (4.8 and 5\%) of hemolytic activity toward cow and rabbit RBCs still standing to the acceptable level. Statistical analysis of the data revealed that the increases in hemolytic activity of the purified peptides toward human, cow and rabbit RBCs are significant at the concentrations of 75 and $100 \mu \mathrm{g} / \mathrm{ml} . D f, F$ and $P$ values are illustrated in Table (5). In such cases, the significant increase could be neglected (i.e. 
considered to be standing to the acceptable level at all tested concentrations up to 100 $\mu \mathrm{g} / \mathrm{ml}$ ), because the increase in hemolytic activity was compared to zero value (for concentration up to $50 \mu \mathrm{g} / \mathrm{ml}$ ) (Table 5).

Table 5: Hemolytic activity of the purified peptides against human, cow and rabbit red blood cells.

\begin{tabular}{|c|c|c|c|c|c|c|}
\hline \multirow{2}{*}{ Treatment } & \multicolumn{6}{|c|}{ \% Hemolysis $(\mu \mathrm{g} / \mathrm{ml})$} \\
\cline { 2 - 7 } & \multicolumn{3}{|c|}{ Peptide\# A } & \multicolumn{3}{c|}{ Peptide\# B } \\
\cline { 2 - 7 } & Human RBCs & Cow RBCs & Rabbit RBCs & Human RBCs & Cow RBCs & Rabbit RBCs \\
\hline Control & $0^{\mathrm{a}}$ & $0^{\mathrm{a}}$ & $0^{\mathrm{a}}$ & $0^{\mathrm{a}}$ & $0^{\mathrm{a}}$ & $0^{\mathrm{a}}$ \\
\hline $12.5 \mu \mathrm{g}$ & $0^{\mathrm{a}}$ & $0^{\mathrm{a}}$ & $0^{\mathrm{a}}$ & $0^{\mathrm{a}}$ & $0^{\mathrm{a}}$ & $0^{\mathrm{a}}$ \\
\hline $25 \mu \mathrm{g}$ & $0^{\mathrm{a}}$ & $0^{\mathrm{a}}$ & $0^{\mathrm{a}}$ & $0^{\mathrm{a}}$ & $0^{\mathrm{a}}$ & $0^{\mathrm{a}}$ \\
\hline $50 \mu \mathrm{g}$ & $1.40 \pm 0.24^{\mathrm{a}}$ & $1.60 \pm 0.25^{\mathrm{a}}$ & $1.80 \pm 0.37^{\mathrm{b}}$ & $0^{\mathrm{a}}$ & $0^{\mathrm{a}}$ \\
\hline $75 \mu \mathrm{g}$ & $3.60 \pm 0.51^{\mathrm{b}}$ & $3.40 \pm 0.51^{\mathrm{ab}}$ & $3.20 \pm 0.37^{\mathrm{b}}$ & $2.80 \pm 0.37^{\mathrm{b}}$ & $3.00 \pm 0.32^{\mathrm{b}}$ & $2.60 \pm 0.40^{\mathrm{b}}$ \\
\hline $100 \mu \mathrm{g}$ & $4.40 \pm 0.51^{\mathrm{b}}$ & $4.80 \pm 0.66^{\mathrm{b}}$ & $5.00 \pm 0.63^{\mathrm{b}}$ & $2.80 \pm 0.37^{\mathrm{b}}$ & $2.80 \pm 0.20^{\mathrm{b}}$ & $3.40 \pm 0.25^{\mathrm{b}}$ \\
\hline$d f, F, P$ & $5,40.46,0.00$ & $5,33.40,0.00$ & $5,38.49,0.00$ & $5,44.80,0.00$ & $5,96.29,0.00$ & $5,67.20,0.00$ \\
\hline
\end{tabular}

*Means with different letters are significant at $95 \%$ confidence limits.

\section{Native and SDS-PAGE, and localization of the antimicrobial activity}

The native forms of the purified proteins were analyzed by electrophoresis system for basic proteins. Fig. (1A) shows that the isolated peptides (A and B) are essentially pure. However, peptide B contained a single impurity which moved faster than the main spot, causing irregular shape of the band.

The immunized haemolymph was subjected to native-PAGE at intervals after bacterial injection, and the antibacterial activities were detected by overlaying bacteria seeded agar. Fig. (1B) showed that that seeding of E. coli on top of a gel provided a means to demonstrate the antibacterial activity of proteins. A localized antibacterial activity of two protein bands with distinct electrophoretic mobility was demonstrated using bacteria seeded agar method. Meanwhile, no antibacterial activity was detected in the case of non-immunized haemolymph (Fig. 1B).

Fig. (1E) showed the two peptides with low molecular weight (A and B), and exhibiting relative higher antimicrobial activity. The molecular weights of the two peptides as revealed by Tricine SDS-PAGE were 5.8 and $4.3 \mathrm{KDa}$, respectively (Fig. $1 \mathrm{E})$.

\section{DISCUSSION AND CONCLUSION}

Defense peptides and proteins constitute key factors in insect humoral immune response against invading microorganisms. It is generally assumed that each insect species possesses an individual set of antimicrobial peptides synthesized in response to non-self recognition. In this study, we purified and partially characterized two $B$. mori peptides which appeared in larval haemolymph after bacterial challenge. They probably comprise a part of the defense peptide repertoire of $B$. mori. The significant increase of the bacterial-challenged haemolymphs suggested that the AMPs are upregulated and released in haemolymph as "acute phase response" of the insect and then declined over time. Agreeable results were reported by Brogden et al. (2003) who stated that after immunization, the level of antimicrobial activity in the haemolymph increases significantly. Also, it was clear that this response differ in correspondence to inducer (bacterial strain). The observation that a gram (-) inducer was more efficient than a combination needs more investigation, especially at molecular level. Consequently, full antimicrobial activity of the immune haemolymph was observed at $24 \mathrm{~h}$ p.i. These results are consistent to the results of quantitative protein analysis. The immune haemolymph is then fractionated and one of the tested 
fractions exhibited higher antimicrobial activity. Finally, two peptides (5.8 and 4.3 $\mathrm{KDa})$ were purified and one of them $(4.3 \mathrm{KDa})$ showed full antimicrobial activity and very weak hemolytic activity up to concentration of $100 \mu \mathrm{g} / \mathrm{ml}$. Early immunological studies conducted at the beginning of the $20^{\text {th }}$ century, were focused on the role of the morphologic elements of the haemolymph. At that time, a strong, heat-stable haemolymph antibacterial activity was observed after insect immunization. Late 1970s brought a series of biochemical investigations on immunized insects that resulted in isolation of novel classes of antimicrobial peptides called cecropins and attacins (Chadwick et al., 1991). Presently, the insect haemolymph is one of the richest sources of novel antimicrobial agents; the number of novel inducible antibacterial peptides of insects exceeds now 180. Additionally, antimicrobial peptides are assumed as an alternative for the classical antibiotics. They are advantageous because their selectivity, fast killing, broad antimicrobial spectra and no resistance development (Matsuzaki, 1999, Boman, 2003). As it was stated earlier, many antimicrobial peptides have been discovered in insects. In Drosophila melanogaster, more than 20 antimicrobial peptide genes were identified and their peptide products were grouped into seven families: attacins, cecropins, defensins, diptericins, drosomycins, drosocin and metchnikowin (Irving et al., 2004). Although D. melanogaster is the best characterized organism concerning insect innate immunity, the first insect inducible antibacterial peptides, cecropins, were isolated and characterized from bacteria-challenged pupae of the lepidopteran insect, Hyalophora cecropia (Steiner et al., 1981). Since then peptides with antimicrobial activity have been purified and described in many other insect species belonging to different orders: Lepidoptera, Diptera, Coleoptera, Hymenoptera, Hemiptera, Trichoptera and Odonata (Hetru et al., 1981). Recently, the lepidopteran insect, Galleria mellonella, has been developed as a model organism for studying innate immunity mechanisms (Cotter et al., 2000, Leger, et al., 2000, Brennan et al., 2002, Dunphy et al., 2003, Reeves et al., 2004, Kavanagh and Reeves, 2004, Mylonakis et al., 2005). So far, more than 13 inducible G. mellonella peptides with antimicrobial activity have been characterized (Schuhmann et al., 2003, Kim et al., 2004, Lee et al., 2004, Cytryńska et al., 2007). Antimicrobial peptide homologous to B. mori cecD and a proline-rich peptide of unique amino acid sequence were purified by Mak et al. (2001) however, the antimicrobial activity spectrum of both peptides was not determined.

Conclusively, we demonstrated that the antimicrobial activity of the immune haemplymph is related to the presence of two peptides that are able to kill bacteria. The present work describes purification and partial characterization of these two antimicrobial peptides. Molecular studies on such peptides will be very helpful in understanding their mode of action and structure-function relationships.

\section{REFERENCES}

Boman, H.G. (2003): Antibacterial peptides: basic facts and emerging concepts. J. Intern. Med., 254: 197-215.

Brennan, M.; Thomas, D.Y.; Whiteway, M. and Kavanagh, K. (2002): Correlation between virulence of Candida albicans mutants in mice and Galleria mellonella larvae. FEMS Immunol. Med. Microbiol., 34: 153-7.

Brogden, K.A.; Ackermann, M.; McCray Jr, P.B. and Tack, B.F. (2003): Antimicrobial peptides in animals and their role in host defences. Int J. Antimicrob. Agents., 22: 465-78.

Bulet, P. and Stöcklin R. ( 2005): Insect Antimicrobial Peptides: Structures, Properties and Gene Regulation. Protein and Peptide Letters J., 12: 13-11. 
Bulet, P.; Charlet, M. and Hetru, C. (2003): In Innate Immunity, (Ezekowitz, R.A.B. and Hoffmann, J.A., Eds.) pp. 89-107. Humana Press, Totowa, N.J.

Bulet, P.; Hetru, C.; Dimarcq, J-L. and Hoffmann, D. (1999): Antimicrobial peptides in insects: structure and function. Dev. Comp. Immunol., 23: 329-344.

Chadwick, J.S.; Aston, W.P. and Gupta, A.P. ( 1991): Immunology of insects and other arthropods. pp. 347-370. Boca Raton: CRC Press.

Cotter, G.; Doyle, S. and Kavanagh, K. (2000): Development of an insect model for the in vivo pathogenicity testing of yeasts. FEMS Immunol .Med. Microbiol., 27: 163169.

Cytryńska, M.; Mak, P.; Zdybicka-Barabas, A.; Suder, P. and Jakubowicz, T. (2007): Purification and characterization of eight peptides from Galleria mellonella immune haemolymph. Peptides, 28: 533-546.

Dandin, S.B.; Jayant J. and Giridhar, K. (2003): Hand Book of Sericulture Technologies. Central Silk Board, Bangalore, India, 53.

Dunphy, G.B.; Oberholzer, U.; Whiteway, M.; Zakarian, R.J. and Boomer, I. (2003): Virulence of Candida albicans mutants toward larval Galleria mellonella (Insecta, Lepidoptera, Galleridae).Can. J. Microbiol., 49: 514-24.

Favel, A.; Steinmetz, M.D.; Regli, P.; Olivier, E.V.; Elias, R. and Balansard, G. (1994): In vitro antifungal activity of triterpenoid saponins. Planta Med., 60: 50-53.

Gabriel, O. (1971): Analytical disc gel electrophoresis. Methods Enzymol., 22: 565-578.

Hetru, C.; Hoffmann, D.; Bulet, P.; Brey, P.T. and Hultmark, D. (1981): Molecular mechanisms of immune responses in insects. London: Chapman \& Hall., 40-66.

Hoffmann, J.A.; Kafatos, F.C.; Janeway, C.A. and Ezekowitz, R.A. (1999): Phylogenetic perspectives in innate immunity. Science, 284: 1313-1318.

Irving, P.; Troxler, L. and Hetru, C. (2004): Is innate enough? The innate immune response in Drosophila. C.R. Biol., 27: 557-570.

Jacobs, M.R.; Koornhof, H.J.; Robins-Browne, R.M.; Stevenson, C.M.; Vermaak, Z.A.; Freiman, I.; Miller, G.B.; Witcomb, M.A.; Isáacson, M.; Ward, J.I. and Austrian, R. (1978): Emergence ofmultiply resistant pneumococci. New England J. of Med., 299: 735-740.

Kavanagh, K. and Reeves, E.P. (2004): Exploiting the potential of insects for in vivo pathogenicity testing of microbial pathogens. FEMS Microbiol. Rev., 28: 101112.

Kim, C.H.; Lee, J.H.; Kim, I.; Seo, S.J.; Son, S.M. and Lee, K.Y. (2004): Purification and cDNA cloning of a cecropin-like peptide from the great wax moth, Galleria mellonella. Mol. Cells, 17: 262-266.

Lee, Y.S.; Yun, E.K.; Jang, W.S; Kim, I.; Lee, J.H. and Park, S.Y. (2004): Purification, cDNA cloning and expression of an insect defensin from the great wax moth, Galleria mellonella. Insect Mol. Biol., 13: 65-72.

Leger, R.; Screen, S.E. and Shams-Pirzadeh, B. (2000): Lack of host specialization in Aspergillus flavus. Appl. Environ. Microbiol., 66: 320-324.

Maizel, J.V. and Jr, P.B. (1971): Methods in Virology (Maramorosch, K. \& Koprowski, H., eds) Academic Press, New York and London, 5: 179-246.

Mak, P.; Chmiel, D. and Gacek, G.J. (2001): Antibacterial peptides of the moth Galleria mellonella . Acta Biochim. Pol., 48: 1191-1195.

Matsuzaki, K. (1999): Why and how are peptide-lipid interactions utilized for selfdefense? Magainins and tachyplesins as archetypes. Biochim. Biophys. Acta.,1462: 1-10.

Mylonakis, E.; Moreno, R.; El Khoury, J.B.; Idnurm, A.; Heitman, J. and Calderwood, S.B. (2005): Galleria mellonella as a model system to study Cryptococcus neoformans pathogenesis. Infect. Immun., 73: 3842-3850. 
NCCLS (1997): Performance standards for antimicrobial disc suspectibility tests. Approved Standard NCCLS PublicationM2-A5. Villanova, PA, USA.

Reeves, E.P.; Messina, C.G.; Doyle, S. and Kavanagh, K. (2004): Correlation between gliotoxin production and virulence of Aspergillus fumigatus in Galleria mellonella. Mycopathologia, 158: 73-79.

Reinert, R.; Ringelstein, A.; Van der Linden, M.; Yu, M.; Al-Lahham A. and Schmitz, F. (2005): Molecular epidemiology of macrolide-resistant Streptococcus pneumoniae isolates in Europe. J. Clinical Microbiol., 43: 31294-31300.

Ryge, T.S. and Hansen, P.R. (2005): Novel lysine-peptoid hybrids with antibacterial properties. J. Peptide Sci., 11: 727-734.

Schoofs, L.; Holman, G.M.; Hayes, T.K.; Nachman, R.J. and DeLoof, A. (1990): Locust atachykinin I and II, two novel insect neuropeptides with homology to peptides of the vertebrate tachykinin family. FEBS Lett., 261: 397-401.

Schuhmann, B.; Seitz, V.; Vilcinskas, A. and Podsiadlowski, L. (2003): Cloning and expression of gallerimycin, an antifungal peptide expressed in immune response of greater wax moth larvae, Galleria mellonella. Arch. Insect Biochem. Physiol., 53: $125-133$.

Steiner, H.; Hultmark, D.; Engström, A.; Bennich, H. and Boman, H.G. (1981): Sequence and specificity of two antibacterial proteins involved in insect immunity. Nature, 292: 246-248.

Tzou, P.; De Gregorio, E. and Lemaitre, B. (2002): How Drosophila combats microbial infection: a model to study innate immunity and host-pathogen interactions. Curr. Opin. Microbiol., 5: 102-110. 

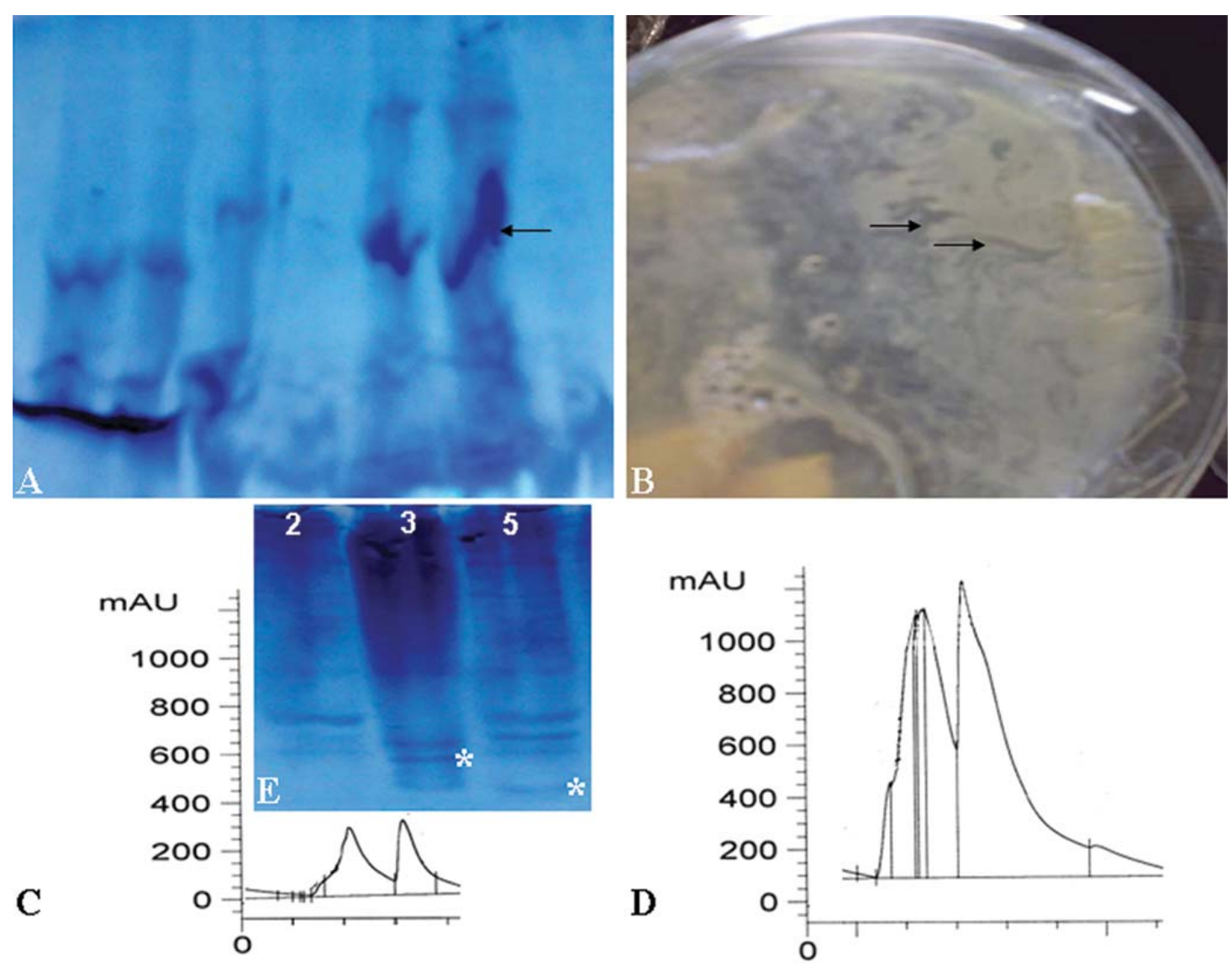

Fig. 1: (A): Native-PAGE showing the induced antimicrobial peptide. (B): localization of the antimicrobial activity on the gel using bacteria seeded agar method. (C\&D): HPLC results indicating two peaks of the purified peptides. (E): SDS-PAGE showing the two antimicrobial peptides at 5.8 and 4.3 KDa molecular mass. Arrows and asterisks indicate the antimicrobial peptides. 


\section{RABIC SUMMARY}

\section{تنقية وتوصيف اثنين من البيتيدات المضادة للميكروبات من دم يرقات فراشة الحرير بومبيكس موراى

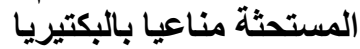

\section{علاء السيوفى 1 و غادة البسيونى 1 و صافيناز ابراهيم²}

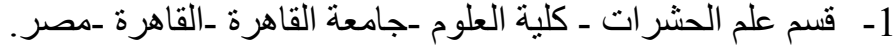

2- قسم الكيمياء الحيوية ـ كلية الصيدلة ـجامعة القاهرة ـالقاهرة ـمصرة.

تشكل البيتيدات و البروتينـات الدفاعيـة عو امل رئيسية في الاستجابة المناعيـة للحشر ات ضد غن غزو الكائنات

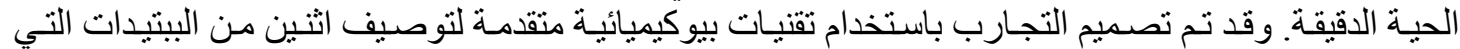

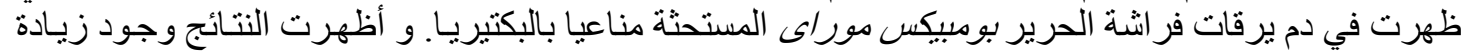

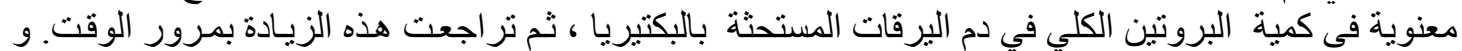

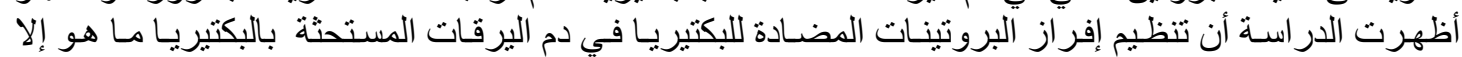

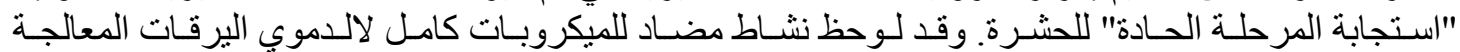

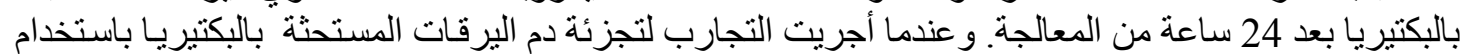

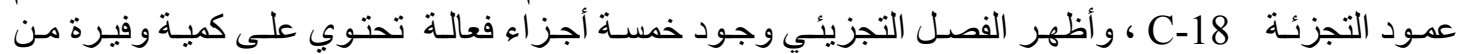

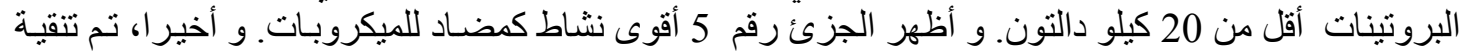

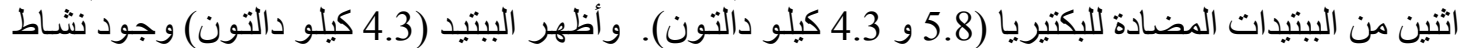

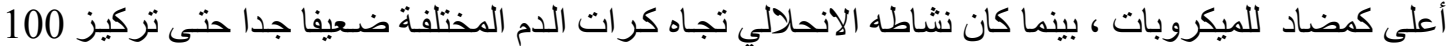

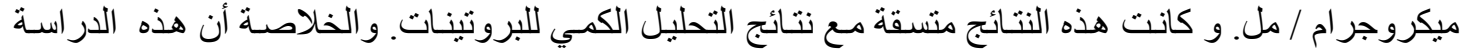

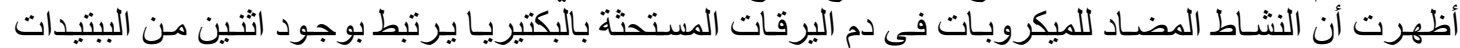

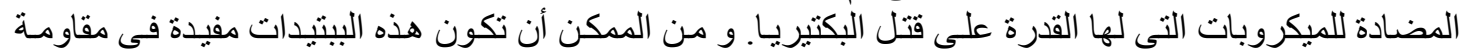
العدوى البكتيرية للنبات و الحيوان الفيان الإنسان. 